\title{
An unusual small-bodied crocodyliform from the Middle Jurassic of Scotland, UK, and potential evidence for an early diversification of advanced neosuchians
}

\author{
Hongyu Yi ${ }^{1,2}$, Jonathan P. Tennant ${ }^{3 *}$, Mark T. Young ${ }^{2}$, \\ Thomas J. Challands ${ }^{2, \#}$, Davide Foffa ${ }^{2 \#}$, John D. Hudson ${ }^{4 \#,}$ \\ Dugald A. Ross ${ }^{5 \#}$ and Stephen L. Brusatte ${ }^{2,6}$
}

${ }^{1}$ Institute of Vertebrate Paleontology and Paleoanthropology, Chinese Academy of Sciences, Beijing, 100044, China

${ }^{2}$ School of GeoSciences, Grant Institute, The King's Buildings, University of Edinburgh, James Hutton Road, Edinburgh EH9 3FE, UK

${ }^{3}$ Department of Earth Science and Engineering, Imperial College London, London, SW6 2AZ, UK

Email: jon.tennant.2@gmail.com

${ }^{4}$ Department of Geology, University of Leicester, University Road, Leicester LEI 7RH, UK

${ }^{5}$ Staffin Museum, 6 Ellishadder, Staffin, Isle of Skye IV51 9JE, UK

${ }^{6}$ National Museums Scotland, Chambers Street, Edinburgh EH1 1JF, UK

* Corresponding author

\# These authors listed alphabetically

\begin{abstract}
The Middle Jurassic is a poorly sampled time interval for non-pelagic neosuchian crocodyliforms, which obscures our understanding of the origin and early evolution of major clades. Here we report a lower jaw from the Middle Jurassic (Bathonian) Duntulm Formation of the Isle of Skye, Scotland, UK, which consists of an isolated and incomplete left dentary and part of the splenial. Morphologically, the Skye specimen closely resembles the Cretaceous neosuchians Pachycheilosuchus and Pietraroiasuchus, in having a proportionally short mandibular symphysis, shallow dentary alveoli and inferred weakly heterodont dentition. It differs from other crocodyliforms in that the Meckelian canal is dorsoventrally expanded posterior to the mandibular symphysis and drastically constricted at the 7th alveolus. The new specimen, together with the presence of Theriosuchus sp. from the Valtos Formation and indeterminate neosuchians from the Kilmaluag Formation, indicates the presence of a previously unrecognised, diverse crocodyliform fauna in the Middle Jurassic of Skye, and Europe more generally. Small-bodied neosuchians were present, and ecologically and taxonomically diverse, in nearshore environments in the Middle Jurassic of the UK.
\end{abstract}

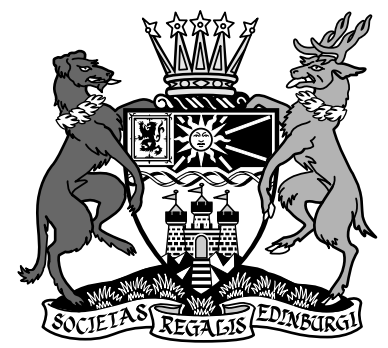

KEY WORDS: Crocodyliformes, Duntulm Formation, Isle of Skye, Neosuchia

Modern crocodiles, caiman, gharials and alligators are the only living members of Crocodyliformes, a group of pseudosuchian archosaurs whose evolutionary history spans about 200 million years (Whetstone \& Whybrow 1983; Benton \& Clark 1988; Bronzati et al. 2015; Mannion et al. 2015). The Middle Jurassic was a key period in their evolution, with thalattosuchians rapidly diversifying in the marine realm (e.g., Gasparini and Chong 1977; Young et al. 2010, 2011; Wilberg 2015). However, much less is known about the non-pelagic crocodyliforms from this time. Apparently, terrestrial and freshwater species were stuck in a low point of their diversity, although this could be an artefact of the notoriously poor Middle Jurassic tetrapod fossil record (Tennant et al. 2016a). Sparse sampling during this interval complicates our understanding of the diversification patterns of non-pelagic crocodyliforms (Bronzati et al. 2015; Mannion et al. 2015; Tennant et al. 2016b), meaning that new Middle Jurassic fossils are critical.

Indeed, crocodyliforms from terrestrial and nearshore assemblages during the Middle Jurassic remain poorly understood compared with those from other geological intervals. During the Late Jurassic, most non-pelagic crocodyliforms in Europe were gonio- pholidids and atoposaurids (Andrade et al. 2011; Young et al. 2016a; Tennant et al. 2016b, c), whereas in other parts of the world, small-bodied sphenosuchian and protosuchian-grade taxa were widely distributed (Gao 2001; Clark et al. 2004; Göhlich et al. 2005; Pol et al. 2013). By the Early Cretaceous, European faunas were composed of a more diverse assemblage of neosuchians, including goniopholidids, pholidosaurids, bernissartiids, putative atoposaurids and hylaeochampsids (e.g., Salisbury \& Naish 2011; Sweetman et al. 2015). Ghost lineage analyses imply that, depending on the systematic position of the Cretaceous clades, some major neosuchian lineages may have originated during the dark period of the Middle Jurassic (e.g., Bernissartiidae, Hylaeochampsidae, Paralligatoridae and Pholidosauridae: Bronzati et al. 2015; Turner 2015; Tennant et al. 2016b).

The problem, however, is that there are currently few known places where Middle Jurassic, non-pelagic crocodyliforms can be found. Jurassic fossil-bearing beds of terrestrial, freshwater and lagoonal origins are sparsely distributed in China (Gao 2001; Maisch et al. 2003; Fu et al. 2005), Kyrgyzstan (Averianov 2000), parts of Europe (Evans \& Milner 1994; Kriwet et al. 


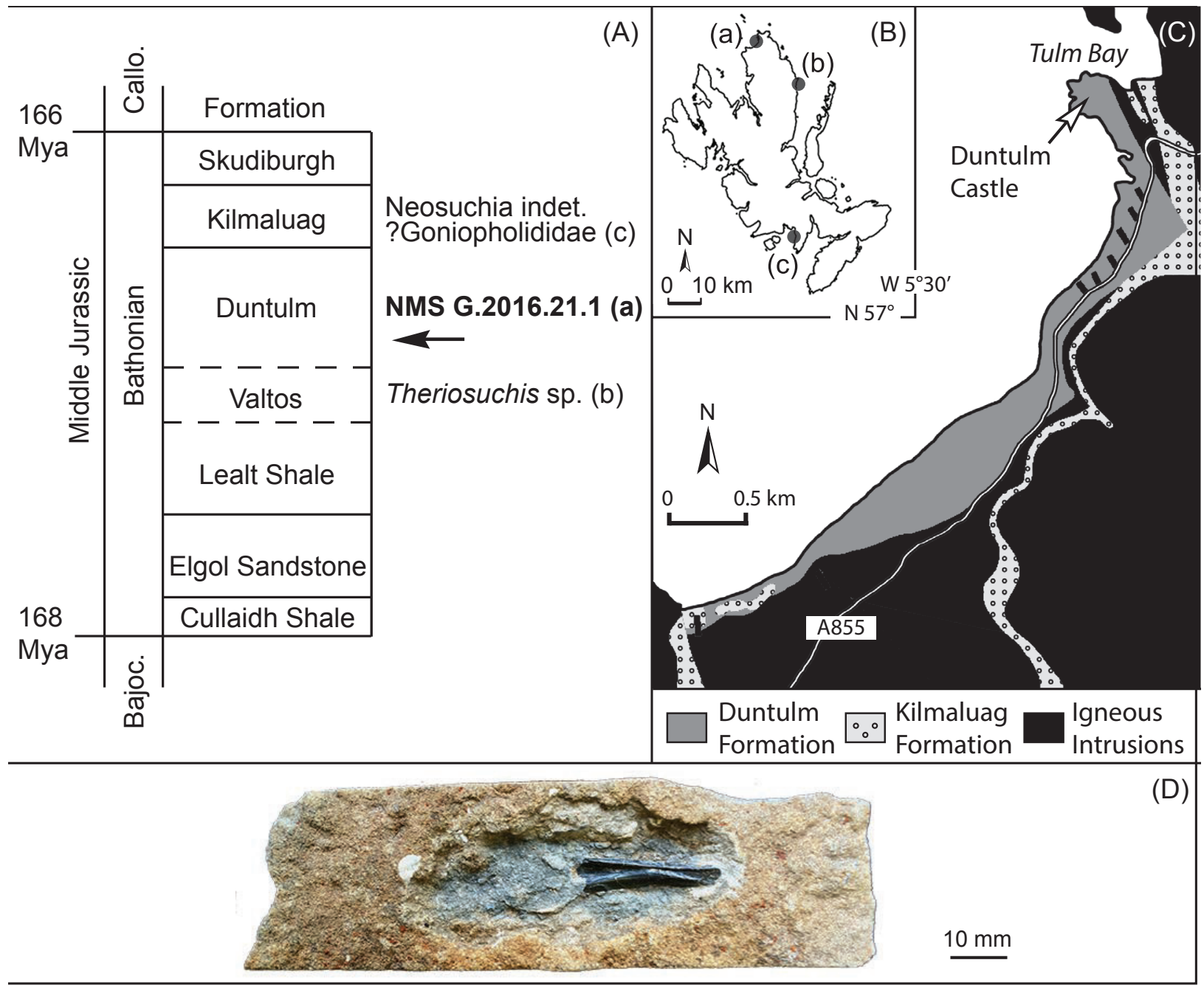

Figure 1 Locality and geological context of NMS G.2016.21.1: (A) stratigraphic occurrences of fossil crocodyliforms discovered from the Great Estuarine Group; (B) map of the Isle of Skye, showing three localities of known fossil crocodyliforms: (a) = Duntulm; (b) = Valtos; (c) = Cladach a'Ghlinne; (C) geological context at the Duntulm locality (a); (D) the new specimen NMS G.2016.21.1.

1997; Knoll et al. 2013; Knoll \& López-Antoñanzas 2014; Young et al. 2016a) and Russia (Kuzmin et al. 2013), which has yielded some crocodyliform fossils. Furthermore, there are undescribed crocodyliform teeth of this age from Thailand (Tong et al. 2002) and possible remains from Madagascar (Dal Sasso \& Pasini 2003; Flynn et al. 2006), but these are fragmentary. The vast majority of Middle Jurassic crocodyliform fossils are isolated specimens from microvertebrate localities - limited evidence that makes it difficult to assign these fossils to higherlevel clades, which in turn hinders our understanding of the origin and early evolution of these groups that would later go on to great diversity and success in the Cretaceous and beyond.

Here we report a new crocodyliform lower jaw from the Middle Jurassic of the Isle of Skye, Scotland, UK (Fig. 1). This study is part of an ongoing investigation of the worldclass Middle Jurassic vertebrate fossil record of Skye, led by the PalAlba Group (Brusatte et al. 2015, 2016; Brusatte \& Clark 2015; Young et al. 2016a). Previously identified crocodyliforms from Skye include indeterminate remains (Evans et al. 2006; Wills et al. 2014) and a partial skeleton (Evans \& Waldman 1996) from Cladach a'Ghlinne (Fig. 1B) and, most recently, a partial lower jaw assigned to Theriosuchus sp. (Young et al. 2016a) from Valtos (Fig. 1B). The new specimen here represents a hitherto unknown small-bodied taxon from the Middle Jurassic Skye tetrapod assemblage, and has impli- cations for the diversity and ecology of non-pelagic crocodyliforms of the poorly-sampled Middle Jurassic.

Note, that herein we use the term Hylaeochampsidae in a broad sense, referring to taxa previously referred to Hylaeochampsidae (compare this clade's taxonomic composition in Buscalioni et al. 2011; Puértolas-Pascual et al. 2014; Narváez et al. 2015; Turner 2015; Schwarz et al. 2017). We use the term 'putative hylaeochampsid' for species with no consensus on their phylogenetic position; i.e., Pachycheilosuchus trinquei Rogers, 2003 and Pietraroiasuchus ormezzanoi Buscalioni et al., 2011, as some phylogenetic analyses fail to recover them within Hylaeochampsidae or within a derived neosuchians position (e.g., Narváez et al. 2015; Tennant et al. 2016c). In addition, a recent study using the Turner (2015) matrix recovered the susisuchids Susisuchus and Isisfordia to be paraphyletic, and both to be within Hylaeochampsidae sensu lato (Schwarz et al. 2017), highlighting the uncertainty in the taxonomic composition of this clade at present.

Institutional abbreviations. AMNH, American Museum of Natural History, New York, USA; IPFUB, Institut für Paläontologie der Freie Universität Berlin, Berlin, Germany; NHMUK, Natural History Museum, London, UK; NMS, National Museums Scotland, Edinburgh, UK; PC-1, provisional specimen number for Pietraroiasuchus ormezzanoi Buscalioni et al., 2011 at Museo Regionale di Scienze Naturali di Torino, 
Italy; SMU, Shuler Museum of Paleontology, Southern Methodist University, Dallas, Texas, USA.

\section{Systematic Palaeontology}

Crocodyliformes Benton \& Clark, 1988

Mesoeucrocodylia Whetstone \& Whybrow, 1983

Neosuchia Benton \& Clark, 1988

Neosuchia $c f$. Hylaeochampsidae

Specimen. NMS G.2016.21.1: an isolated and incomplete, three-dimensionally preserved left lower jaw, including much of the dentary and part of the splenial. The specimen preserves the complete anterior margin of the dentary, but it is broken posteriorly at the 14 th alveolus.

Possible unity with hylaeochampsids. Neosuchia $c f$. Hylaeochampsidae (NMS G.2016.21.1) resembles the putative hylaeochampsids Pachycheilosuchus and Pietraroiasuchus in having shallow dentary alveoli, mildly heterodont dentition and a proportionally short mandibular symphysis extending to the anterior border of the 4 th alveolus.

Differential diagnosis. NMS G.2016.21.1 differs from other neosuchians in having an extremely reduced lingual projection along the mandibular symphyseal suture and in having neurovascular foramina present medial to the tooth row, with a oneto-one association with the tooth sockets from alveoli 5-9. NMS G.2016.21.1 differs from Pachycheilosuchus in having a Meckelian canal that is markedly constricted at the 7th alveolus, and it differs from Pietraroiasuchus in having dentary alveoli that are tightly arranged. Furthermore, the new specimen (NMS G.2016.21.1) differs from all other hylaeochampsids in that its 6th dentary alveolus is smaller than the 5th and 7th and slightly raised from the tooth row.

Locality. The specimen was collected from bed 46 of the type section of the Duntulm Formation at the southern part of the exposures [NG407 734] at Cairidh Ghlumaig, Isle of Skye, Scotland, United Kingdom (Morton \& Hudson 1995, figs 35-36, table 2; Fig. 1C).

The Duntulm Formation (Bathonian, Middle Jurassic) is part of the Great Estuarine Group, (Anderson 1948), which crops out in portions of the northwest Highlands of Scotland, including the Isles of Skye, Raasay, Eigg and Muck (Harris \& Hudson 1980). It consists of sedimentary rocks of marginal marine and non-marine origin, deposited in the Hebrides Basin during the Bathonian of the Middle Jurassic (Harris \& Hudson 1980).

Seven formations belong to the Great Estuarine Group (Fig. 1A). The upper formations of the Group, following an initial transgression across the fluvial deltas of the Valtos Formation, were deposited during a phase of marine regression (Andrews 1985). It shows a transition from shelly limestone, shale and mudstone in the Duntulm Formation (Andrews \& Walton 1990), to interbedded shale, fine-grained limestone and dolomite (with desiccation cracks) and fine-grained sandstones in the freshwater lagoonal Kilmaluag Formation and, finally, to silty clay, coarse sandstone and intraformational conglomerates in the fluvial Skudiburgh Formation (Andrews 1985).

The Duntulm Formation represents the nearest approach to marine conditions within the Great Estuarine Group. The strata from which NMS G.2016.21.1 was collected have one of the most marine-dominated molluscan faunas within the Duntulm Formation as a whole. In these beds, the small oyster Praeexogyra, which forms nearly monotypic shell beds that dominate much of the formation, is joined by bivalve genera such as Camptonectes, Placunopsis, Corbula and Modiolus, and by echinoid spines, all indicative of shallow marine environment
(Andrews \& Walton 1990). The trace fossil Thalassinoides indicates the presence of burrowing crustaceans (Myrow 1995).

With that said, the Duntulm facies are not simply marine. Cyanobacterial ('algal') limestones interbedded with the oysterbearing limestones show evidence of both subaerial exposure and freshwater flushing (Andrews 1986). Carbon, oxygen and strontium isotopic studies of the oysters show that the lagoons where they lived were at times isolated from the sea and suffered evaporation (Holmden \& Hudson 2003). An intercalation of strata bearing the bivalves Unio and Neomiodon, a few metres above where NMS G.2016.21.1 was discovered, emphasises the potential for freshwater input, confirmed by the isotopic investigations. A scenario depicting the overall environment was presented by Hudson \& Trewin (2003). Dinosaur fossils, most notably the trackways of large sauropods, are now known from the lower part of the formation (Brusatte et al. 2016), northeast of where NMS G.2016.21.1 was collected.

Bed 46, from which the crocodyliform specimen came, is sandier than the surrounding beds. Unlike them, it yields the freshwater alga Bothrococcus, probably washed in along with the sand (Andrews \& Walton 1990). In NMS G.2016.21.1, the matrix surrounding the bone is greenish grey sandstone that weathers to a buff-orange colour (Fig. 1D). Besides the crocodyliform jaw, the matrix preserves fish scales, fish teeth and shells of the oyster Praeexogyra. The small oysters are preserved isolated and broken, confirming a high-energy nearshore environment. It is possible that the crocodyliform jaw was washed in; however, given that the dominant fauna of bed 46 is of marine-related genera, we consider NMS G.2016.21.1 most likely to have been a lagoonal species.

Preparation and scanning. Physical preparation exposed the medial surface of the jaw and most of the dorsal surface of the tooth row, whereas the lateral surface and the anterior tip of the dentary remain embedded within the matrix (Fig. 1D). We used high-resolution X-ray computed tomography (HRCT) to visualise the entire specimen, including the embedded portions (Fig. 2). We scanned the fossil in a custom-built machine (constructed and operated by Dr Ian Butler) at the School of GeoSciences, University of Edinburgh, using a 240 kv GE Xray generator. The scan has a resolution of $44 \mu \mathrm{m}$, which was performed under $2.8 \mathrm{w}$ power and with a $0.8 \mathrm{~mm}$ Aluminium filter.

\section{Description}

The preserved lower jaw shows no obvious taphonomic distortion or post-mortem damage, apart from the break at the posterior end. The specimen is laterally compressed, measuring $28 \mathrm{~mm}$ anteroposteriorly, $6 \mathrm{~mm}$ dorsoventrally at the deepest point and less than $4 \mathrm{~mm}$ labiolingually (Fig. 2). The posterior margin terminates at the 14th dentary alveolus (D14); therefore, we cannot assess the total number of dentary teeth (Fig. 2A-B). The irregular shape of this posterior margin suggests it represents a fracture, rather than the anterior margin of the external mandibular fenestra. This means that the specimen preserves the anterior part of the left dentary and a small fragment of the splenial (Fig. 2E-H). The angular and surangular are not preserved, and we cannot determine whether a mandibular fenestra was present.

\subsection{Dentary}

In dorsal view, the dental arcade occupies almost the entire mediolateral width of the occlusal surface of the lower jaw. The anterior tooth row has a medial ridge extending between the 2nd and 9th alveoli (D2-D9), which provides an elongate articulation surface for the splenial. We estimate that the splenial extended as far anteriorly as the anterior border of 
(A)

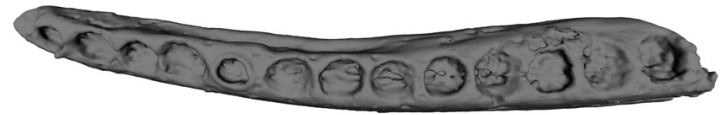

(C)

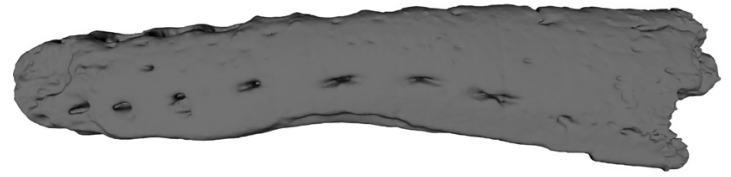

(E)

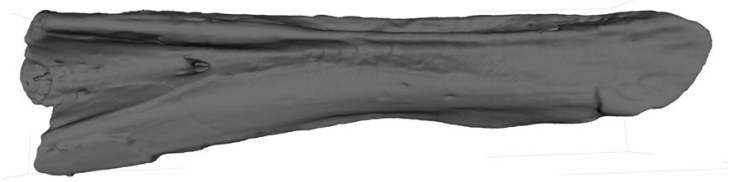

(G)

Anterior
(B)

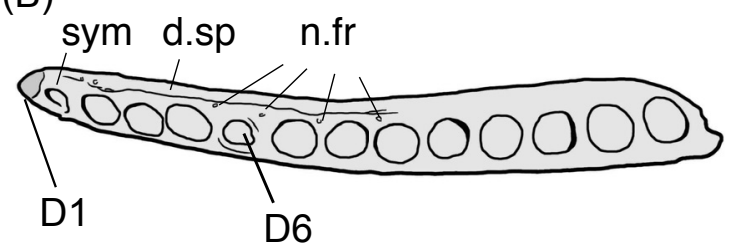

(D)

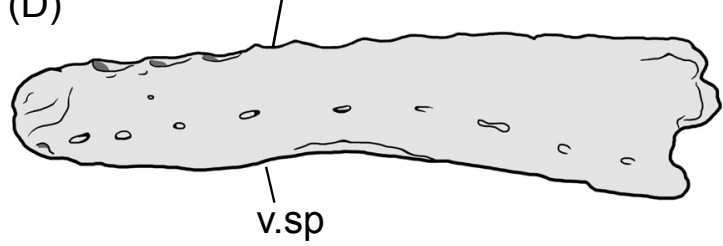

$(\mathrm{F})$

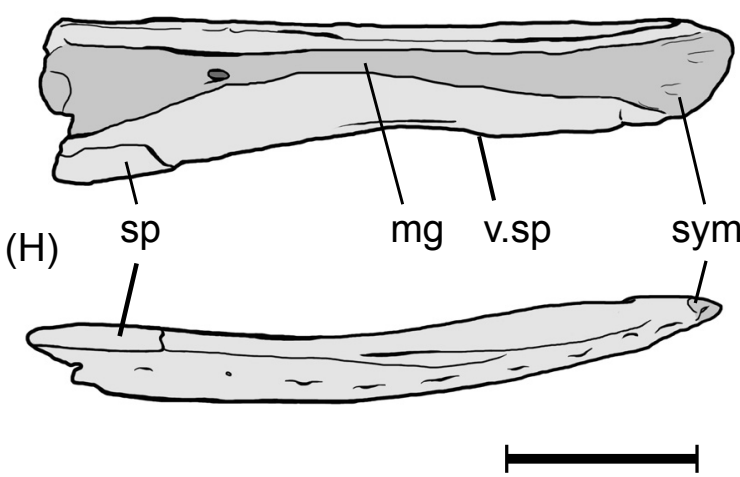

Figure 2 CT models and line drawings of specimen NMS G.2016.21.1: (A-B) dorsal view; (C-D) lateral view; $(\mathrm{E}-\mathrm{F})$ medial view; $(\mathrm{G}-\mathrm{H})$ ventral view. Anatomical abbreviations: D1 = first dentary tooth; D6 = sixth dentary tooth; d.sp = dentary articulation surface for the splenial; $\mathrm{mg}=$ Meckelian groove; $\mathrm{n}$. fr $=$ neurovascular foramina; $\mathrm{sp}=$ splenial; sym = mandibular symphysis; v.sp = ventral articulation surface for the splenial. Scale bar $=10 \mathrm{~mm}$.

(A)

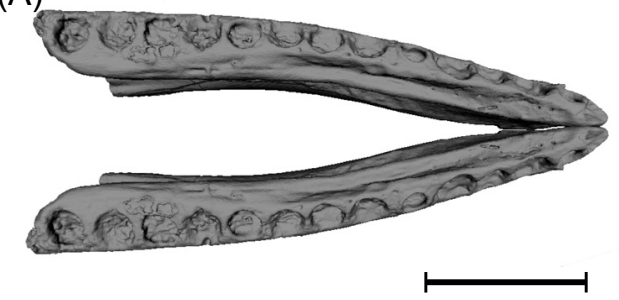

(B)

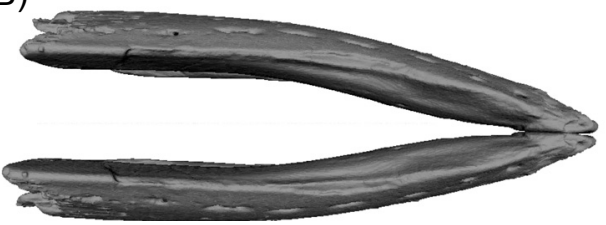

Figure 3 Reconstructed CT models of the anterior mandibles of NMS G.2016.21.1: (A) dorsal view; (B) ventral view. Scale bar $=10 \mathrm{~mm}$.

the 6th alveolus (Fig. 2: v.sp). Neurovascular foramina are present medial to the tooth row. Anterior to the 5th alveolus (D5), these foramina are irregularly distributed. From D5 to D9, one foramen is located posterior to each alveolus in the raised tooth row (Fig. 2B).

In lateral view, the dentary has a straight dorsal margin and a concave ventral margin. It gradually tapers dorsoventrally towards the anterior tip and medially into the symphysis (Fig.
2C-D). A series of ten evenly-spaced neurovascular foramina occupy the lateral external surface of the bone. The row of foramina follows the curvature of the ventral margin of the dentary.

Medially, the mandibular symphysis fully occupies the anterior tip of the dentary. The symphysis is anteroposteriorly short in proportion to the dentary, ending at the anterior border of the 4th alveolus (D4). The symphyseal surface bears longitudinal striations for articulation, distinct from deep rugosities in many mesoeucrocodylians (Holliday \& Nesbitt 2013). The Meckelian canal enters the symphyseal plate anteriorly and continues along the entire length of the preserved dentary. It shows a distinct dorsoventral constriction at the 7th alveolus (D7), followed by a trumpet-shaped expansion that opens to the truncated posterior margin of the specimen. A large neurovascular foramen is located in the Meckelian canal posterior to the constricted area, beneath the 11th alveolus (D11). A small fragment of splenial is preserved at the posteroventral margin of the dentary, and the splenial does not appear to have contributed to the symphysis (Fig. 2).

The ventral profile of the dentary is labiolingually narrow. The dentary curves towards the midline of the skull from the 6th alveolus (D6) to the anterior tip (Fig. 2A-B, G-H). We digitally mirrored the specimen to reconstruct a composite full lower jaw for NMS G.2016.21.1. The reconstructed mandibles display a tapering tip at the symphysis (Fig. 3), compared with the more rounded or U-shape outline in most crocodyliforms (Romer 1956). 


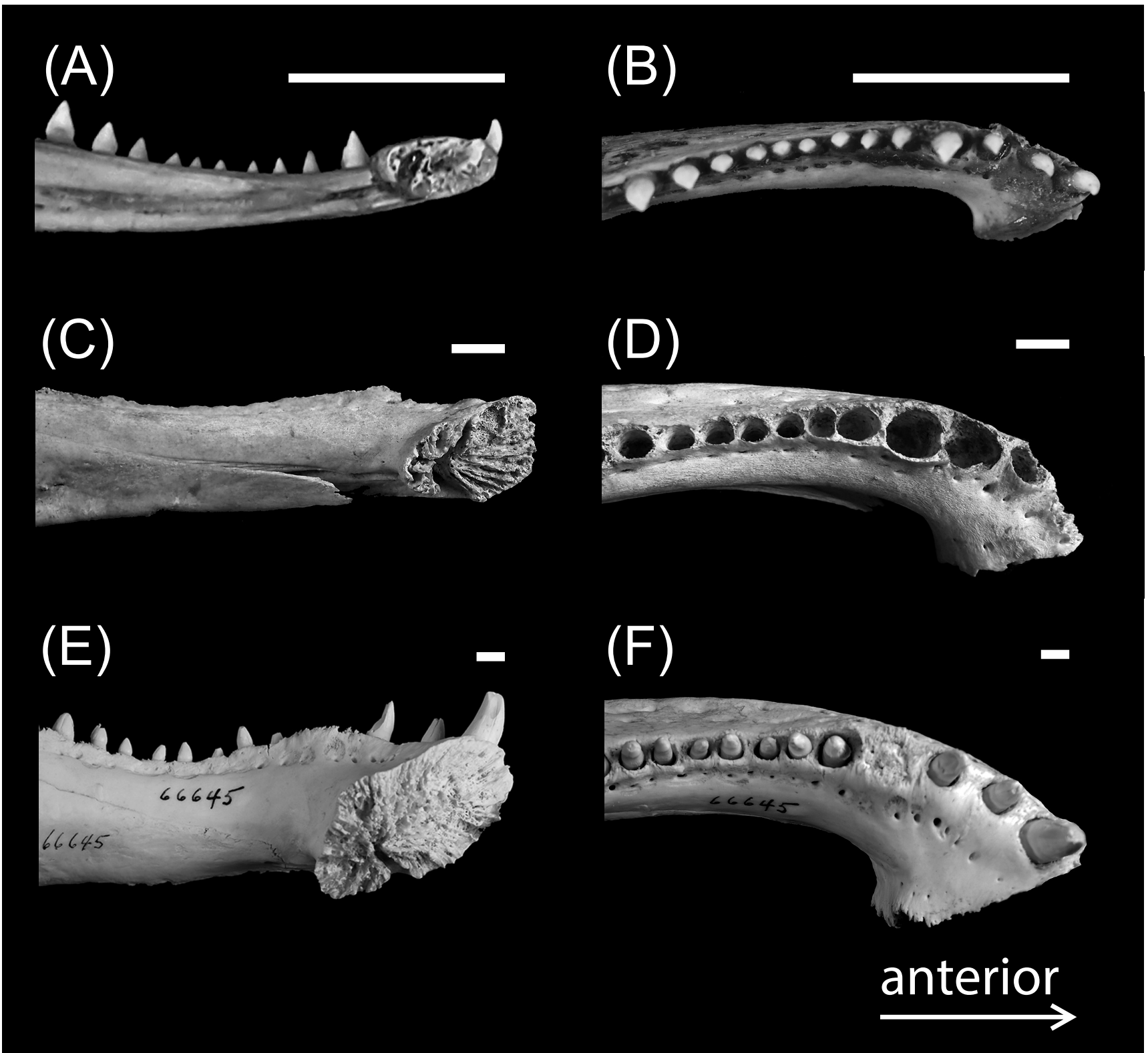

Figure 4 The mandibular symphysis of Alligator mississippiensis through ontogeny: (A-B) left mandibular rami of a hatchling (AMNH R7129): (A) medial view; (B) dorsal view; (C-D) a medium-sized individual (AMNH R7140): (C) medial view; (D) dorsal view; (E-F) an adult (AMNH R66645): (E) medial view; (F) dorsal view. Scale bars $=10 \mathrm{~mm}$.

\subsection{Alveoli}

The dentary preserves 14 alveoli, but no teeth are preserved fully or partially in situ, nor are any associated tooth crowns present within the surrounding matrix. The first five alveoli (D1-D5) are longitudinally elongated and labiolingually compressed, whereas the posterior alveoli (D6-D14) are round. No caniniform tooth is observed in the specimen. Most of the alveoli measure approximately $1.5 \mathrm{~mm}$ in diameter, with the 1st, 2nd and 6th alveoli being about half the size of adjacent ones (Fig. 2A-B). Therefore, we infer that the lower jaw dentition was mildly heterodont, with two tooth "waves". Each alveolus is separated by an interalveolar septum; the first two septa and those posterior to D6 are approximately uniform in width, but those between D3-D5 are almost absent. The septa surrounding the 6th alveolus (D6) are marginally wider, as this alveolus is slightly raised from the tooth row. The preserved alveoli are shallow, extending no deeper than the dorsal margin of the Meckelian canal.

\subsection{Developmental stage}

With 14 alveoli, the preserved portion of the dentary measures $28 \mathrm{~mm}$ (D1-D14). A row of the same number of dentary alveoli measures $30 \mathrm{~mm}$ in Knoetschkesuchus (IPFUB Gui Croc 8109: Schwarz \& Salisbury 2005; Schwarz et al. 2017), 40-45 mm in Pachycheilosuchus (SMU 75278: Rogers 2003) and Pietraroiasuchus (PC-1: Buscalioni et al. 2011), and about $65 \mathrm{~mm}$ in Goniopholis (NHMUK PV OR 48300: Salisbury 2002), which are small-bodied neosuchians, all appearing to be represented by anatomically mature specimens. Therefore, NMS G.2016.21.1 is smaller than an adult, and generally matches the size of a sub-adult or juvenile, when compared with the above taxa. When compared with the extant crocodylian Alligator mississippiensis Daudin, 1802 (a medium-large bodied eusuchian), NMS G.2016.21.1 is equivalent to a hatchling in size (Fig. 4). Future discoveries of fossil material may help better assess the developmental stage of this new Skye specimen. 


\section{Crocodyliform affinity of NMS G.2016.21.1}

The Middle Jurassic of the Isle of Skye yields a diverse array of archosaurs, lepidosaurs, choristoderes, stem mammals and marine reptiles (e.g., Waldman \& Savage 1972; Clark et al. 1995; Evans \& Waldman 1996; Evans et al. 2006; Wills et al. 2014; Brusatte et al. 2015, 2016; Brusatte \& Clark 2015; Close et al. 2016; Young et al. 2016a). NMS G.2016.21.1 differs from lepidosaurs and choristoderes in having thecodont dentition with rounded alveoli and a single row of neurovascular foramina on the lateral surface (Romer 1956; Gao \& Fox 1998). It also differs from ichthyosaurs in having shallow tooth sockets: some Triassic ichthyosaurian taxa have thecodont dentition, but their tooth roots attach deeply in the jaw bones (Motani 1997). The dentary of NMS G.2016.21.1 lacks tooth replacement pits, which contrasts with the multiple rows of dentary teeth in eosauropterygians (Sassoon et al. 2015). Amongst archosaurs, NMS G.2016.21.1 differs from dinosaurs in having the long Meckelian canal extending into the mandibular symphysis (Romer 1956; Holliday \& Nesbitt 2013). A pterosaur affinity is unlikely, as they generally have elongate mandibular symphysis (Romer 1956).

Crocodyliforms and some derived "sphenosuchians" have the Meckelian canal extending into the mandibular symphysis (Nesbitt 2011), which is the same as in NMS G.2016.21.1. However, "sphenosuchians" have a proportionally longer mandibular symphysis than the new specimen (Colbert \& Mook 1951; Clark \& Sues 2002; Clark et al. 2004; Pol et al. 2004). In non-crocodyliform diapsids, the neurovascular foramina are limited to a single line near the dorsal margin of the dentary, whereas in crocodyliforms the neurovascular foramina are more numerous and form a "beehive" arrangement, which is associated with the presence of dome pressure receptors (Soares 2002). The arrangement of dentary foramina in NMS G.2016.21.1 is consistent with those of crocodyliforms (Soares 2002). Therefore, we exclude NMS G.2016.21.1 from these other groups, and confidently refer it to a small-bodied, juvenile to sub-adult crocodyliform.

\section{Taxonomic comparisons within Crocodyliformes}

As mentioned previously, there is a diverse range of Middle Jurassic crocodyliform clades either known from fossils or inferred from ghost lineages to which NMS G2016.21.1 could potentially be assigned. Here, we provide extensive comparisons to all clades as a process of elimination to deduce a likely candidate clade for the specimen.

The new specimen (NMS G2016.21.1) has a short mandibular symphysis, shallow dentary alveoli and inconspicuous dentary ornamentation. It differs from large-bodied aquatic clades that evolved elongate symphyseal sutures and lower jaws, such as Thalattosuchia, the most commonly discovered and diverse Middle Jurassic crocodyliforms (e.g., Andrews 1913; Pierce \& Benton 2006; Young et al. 2010). Among taxa considered to be "protosuchians", species with a similarly short mandibular symphyseal suture have markedly different dentary morphology when compared with the new specimen. Zosuchus davidsoni Pol \& Norell, 2004a and Gobiosuchus kielanae Osmólska, 1972 are labiolingually expanded at the anterior tip of the dentary (Osmólska et al. 1997; Pol \& Norell 2004a), whereas NMS G.2016.21.1 is labiolingually compressed along the symphyseal suture. Numerous notosuchian genera have anteriorly tapering mandibles with short symphyses, including Araripesuchus (Pol \& Apesteguía 2005; Turner 2006), Notosuchus (Fiorelli \& Calvo 2008), and Malawisuchus (Gomani 1997). However, the dentary of notosuchians is much more sigmoid than in
(A)

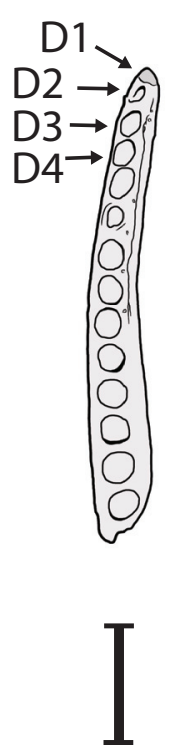

(B)

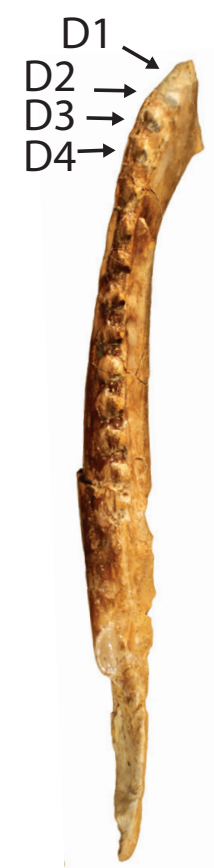

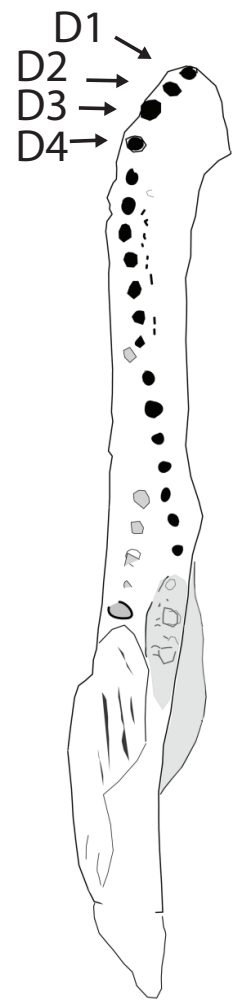

Figure 5 Lower jaw comparisons between NMS G.2016.21.1 and Early Cretaceous hylaeochampsids: (A) the Duntulm specimen (NMS G.2016.21.1); (B) Pachycheilosuchus trinquei (SMU75279). Photograph by D. Winkler; (C) Pietraroiasuchus ormezzanoi (PC-1, modified from Buscalioni et al. 2011). D1-D4 denotes first four alveoli.

NMS G.2016.21.1. Therefore, we consider the referral of NMS G.2016.21.1 to Notosuchia to be unlikely.

The new specimen (NMS G.2016.21.1) also differs from several small-bodied "atoposaurids" known from the UK and across Europe. Theriosuchus sp. from the Middle Jurassic of Skye (Tennant et al. 2016c; Young et al. 2016a) has deeper rugosities in the symphyseal plate, more prominent ornamentation on the lateral surface of the dentary and a different alveolar morphology. Compared with NMS G.2016.21.1, Alligatorium has a curved dorsal margin of the dentary, and Atoposaurus and Alligatorellus have the splenial contributing to the mandibular symphysis; although the latter two most likely represent skeletally immature specimens (Tennant \& Mannion 2014; Tennant et al. 2016c). Montsecosuchus, a small-bodied, phylogenetically uncertain neosuchian from Spain (Buscalioni \& Sanz 1990; Tennant et al. 2016c), has more strongly developed dentary ornamentation than NMS G.2016.21.1.

The Skye jaw (NMS G.2016.21.1) differs from genera consistently found to be hylaeochampsids. Recent analyses that gave conflicting evolutionary positions for the putative hylaeochampsid Pachycheilosuchus do not do so for Acynodon or Iharkutosuchus, instead consistently recovering them within Hylaeochampsidae (e.g., Turner 2015; Narváez et al. 2015; Schwarz et al. 2017). Acynodon, although originally described as being more closely related to crocodylians, is known from the Late Cretaceous of Europe, and includes preserved dentary material for multiple specimens (Delfino et al. 2008a; Martin 2007). However, Acynodon differs from NMS G.2016.21.1 in the vast stratigraphic range disparity, as well as in multiple dentary characteristics: the symphysis extends more than four 


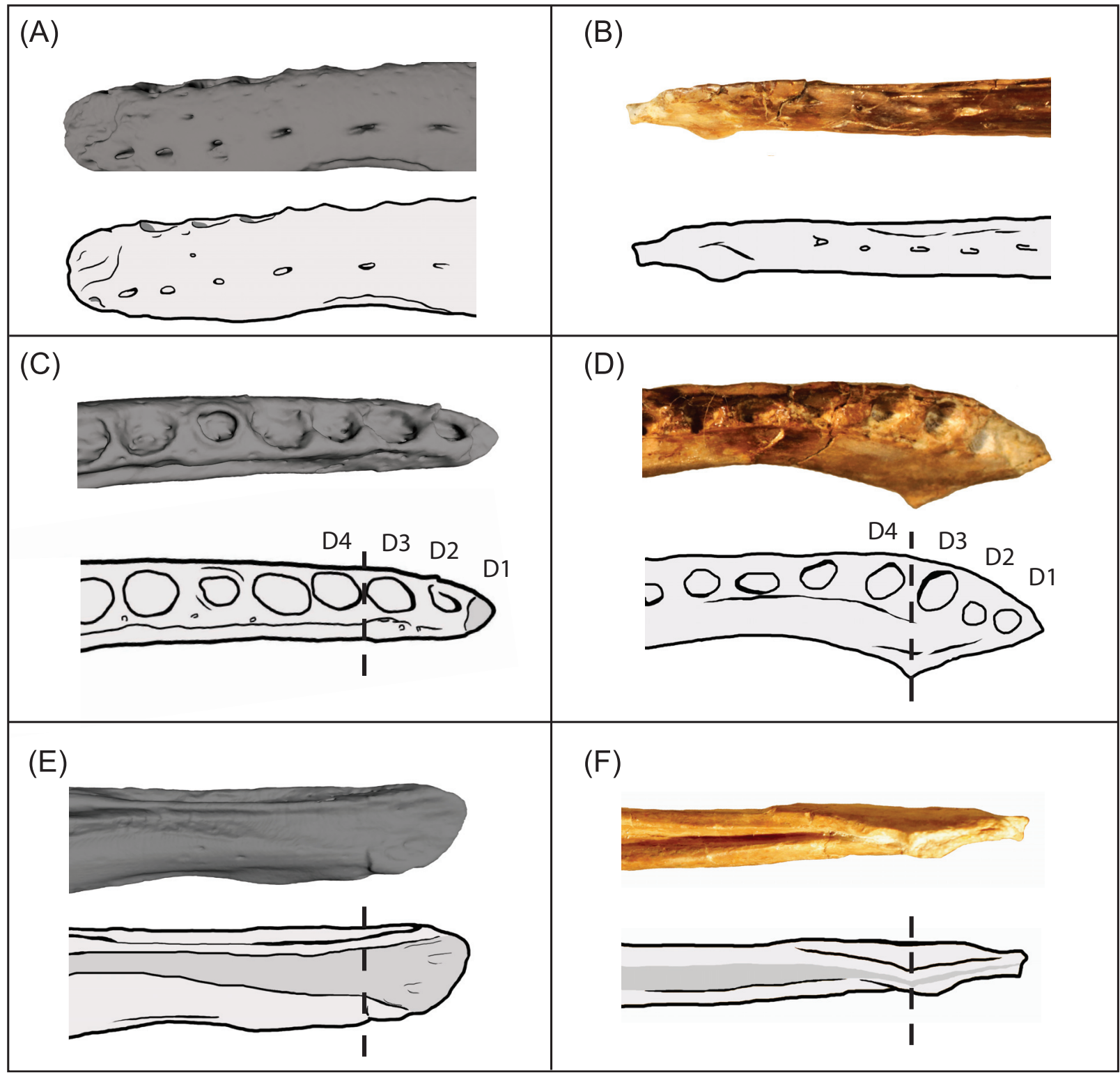

Figure 6 Morphological comparisons between NMS G.2016.21.1 (A, C, E) and Pachycheilosuchus trinquei (SMU75279: B, D, F): (A-B) dentary in lateral view. A row of neurovascular foramina evenly distributes along the lateroventral margin in both taxa; (C-D) dentary in dorsal view. D1-D4 denotes first four alveoli; (E-F) the Meckelian canal expands dorsoventrally in the new specimen, but constricts anteriorly in $P$. trinquei. Dashed lines indicate the posterior limit of the symphyseal plate. Not to scale.

alveoli, the dentary alveoli form a chain and are small and laterally placed relative to the dorsal surface and the ventral surface is greatly mediolaterally expanded and flattened (Delfino et al. 2008a; Martin 2007). The dentary of Iharkutosuchus is distinct from NMS G.2016.21.1 in that the symphysis extends posteriorly to the D8 alveolus, and in that the dental arcade forms an arcuate shape, shifts posteriorly from a lateral position to a more medial position on the occlusal surface, and has a mediolaterally expanded anterior margin similar to other eusuchians (Ösi 2008). Unfortunately, the type species Hylaeochampsa vectiana Owen, 1874 does not preserve the dentary (Clark \& Norell 1992). Similarly, comparison with Allodaposuchus, a possible Late Cretaceous allodaposuchid or putative hylaeochampsid, depending on analysis used (see Buscalioni et al. 2011; Delfino et al. 2008b; Puértolas-Pascual et al. 2014; Narváez et al. 2015), is not possible, as no known specimen preserves the dentary. A recent study extending the Turner (2015) analysis found the susisuchids Susisuchus and Isisfordia to be paraphyletic within an unnamed clade com- prised of all potential hylaeochampsids (Schwarz et al. 2017). The symphyseal region of the mandible of Susisuchus is labiolingually expanded, which differs from NMS G.2016.21.1 (Salisbury et al. 2003). The dentary of Isisfordia cannot be compared with NMS G.2016.21.1, due to the holotype lacking the anterior region (Salisbury et al. 2006; Fortier \& Schultz 2009).

Curiously, NMS G.2016.21.1 is most similar to two species of putative hylaeochampsids (Turner 2015): Pachycheilosuchus trinquei from the Early Cretaceous of Texas, USA (Rogers 2003) and Pietraroiasuchus ormezzanoi from the Early Cretaceous of Italy (specimen PC-1 in Buscalioni et al. 2011). The Skye jaw (NMS G.2016.21.1) shares with Pachycheilosuchus and Pietraroiasuchus a short mandibular symphysis, extending to the anterior border of the 4th alveolus (Figs 5, 6C-F). All three of the taxa have mild heterodont dentition and lack caniniform tooth (inferred for NMS G.2016.21.1 by the absence of any greatly enlarged alveoli). The Skye jaw is similar to Pietraroiasuchus in the gently arcuate form of the arcade in dorsal view, and in 
that the splenial does not contribute to the symphyseal area (Buscalioni et al. 2011). In particular, the Skye jaw shares with Pachycheilosuchus a row of evenly spaced and ventrally positioned neurovascular foramina on the lateral surface of the dentary, which is a unique feature among hylaeochampsids (Fig. 6A-B). However, NMS G.2016.21.1 cannot be assigned to either of the two above genera. It is different from Pietraroiasuchus in the medially expanded anterior occlusal shelf in the latter (Buscalioni et al. 2011). In comparison with NMS G.2016.21.1, most small-bodied neosuchians display varying degrees of labiolingual expansion at the anterior tip of the dentary (Young et al. 2014, fig. 8; Young et al. 2016a, fig. 3; Fig. 5C). The dentary of Pachycheilosuchus has a small lingual projection along the symphyseal suture (Fig. 6D), but the anterior tip of the dentary is less labiolingually compressed than that in the Skye jaw (Fig. 5A-B).

\subsection{Impact of ontogeny on assessment of NMS G.2016.21.1}

The uncertainty of the ontogenetic stage of NMS G.2016.21.1 makes assessing its phylogenetic position problematic. Characters that unite NMS G.2016.21.1 with Pachycheilosuchus, the lack of dentary ornamentation and the shallow articulation rugosities in the symphyseal plate, are known to vary during ontogeny. In extant crocodylians, young individuals have shallow dermatocranial ornamentations that develop into prominent pits and rugosities in adults (Mook 1921; Joffe 1967). But lack of ornamentation may also imply a phylogenetic signal. Several fossil crocodyliforms represented by mature specimens have a smooth or weakly pitted external surface of the dentary. These include several "protosuchian" species (Yang 1973; Wu et al. 1997; Pol \& Norell 2004a, b), various metriorhynchid genera (e.g., Young et al. 2013), the atoposaurid Alligatorium (Tennant \& Mannion 2014), and Pachycheilosuchus (Rogers 2003).

Similarly, shallow rugosities in the symphyseal plate of NMS G.2016.21.1 may be phylogenetically informative, but these rugosities become deeper through ontogeny in extant crocodylians (Fig. 4). The dominant articulation type in Mesoeucrocodylia is Class III symphysis with interdigitated rugosities (Holliday \& Nesbitt 2013), which is lacking in Pachycheilosuchus and NMS G.2016.21.1 (Fig. 6F). The latter two taxa have Class II articulation with shallow rugosities. The uncertain developmental stage of NMS G.2016.21.1 considered, these observations add information to "typical" symphyseal morphology in Neosuchia and potentially more inclusive clades in Crocodyliformes.

The lingual projection of the symphyseal suture remains reasonably stable throughout the ontogeny of extant crocodylians, which we observed in the lower jaw of Alligator mississippiensis (Fig. 4). It retains a labiolingual expansion near the anterior tip of the symphyseal suture, from hatchling-sized juveniles (AMNH R7129; Fig. 4A-B) to medium-sized young individuals (AMNH R7140; Fig. 4C-D), and into skeletal maturity (AMNH R66645; Fig. 4E-F). If Alligator is a good model for the ontogeny of the taxon NMS G.2016.21.1 belongs to, this indicates that the mediolateral constriction of the symphyseal suture observed in NMS G.2016.21.1 may not be an ephemeral juvenile feature, but may also be present in adult individuals; and, therefore, could be potentially diagnostic of a new taxon.

Based on the above comparisons, NMS G.2016.21.1 shares multiple mandibular characteristics with Pachycheilosuchus and Pietraroiasuchus, but its unique symphyseal region differs from all other neosuchians compared herein. We do not name a new taxon, given the incomplete nature of the specimen and its likely juvenile status. Additional skull material and further understanding of ontogenetic changes in crocodyliform mandibles will help assess the phylogenetic position of NMS G.2016.21.1.

\section{Discussion}

Neosuchia $c f$. Hylaeochampsidae (NMS G.2016.21.1) is the first known definitive crocodyliform from the Duntulm Formation, which extends our knowledge of the Middle Jurassic archosaur assemblage of the Isle of Skye (Clark et al. 1995; Evans et al. 2006; Evans \& Waldman 1996; Wills et al. 2014; Brusatte \& Clark 2015; Brusatte et al. 2016; Young et al. 2016a). This specimen differs from other crocodyliforms currently known from Skye, including Theriosuchus sp. (Young et al. 2016a) from the Valtos Formation (Fig. 1A). Theriosuchus sp. has deep dentary ornamentation, strongly heterodont alveoli and a unique "starburst" morphology in the mandibular symphysis (NMS G.2014.52.1: Young et al. 2016a; Fig. 2D), none of which are present in NMS G.2016.21.1. Isolated neosuchian remains are also known from the Kilmaluag Formation that is stratigraphically immediately above the Duntulm Formation (Evans \& Waldman 1996; Evans et al. 2006; Wills et al. 2014). The Kilmaluag material - comprising teeth, osteoderms and incomplete postcranial skeletons - is not directly comparable with NMS G.2016.21.1 due to lack of overlapping skeletal elements. It is possible that these specimens belong to the same taxon as NMS G.2016.21.1 and, if so, one or more of them would make more suitable holotypes, which is one reason we do not name NMS G.2016.21.1 here. These Kilmaluag specimens are currently under study, so their systematics and relationships with NMS G.2016.21.1 will become clearer in the future. These discoveries show that there were various small-sized neosuchians in the nearshore ecosystems of the Isle of Skye during the Middle Jurassic.

\subsection{Implications of NMS G.2016.21.1 as a potential hylaeochampsid}

The morphological resemblance of NMS G.2016.21.1 to Pachycheilosuchus and Pietraroiasuchus could potentially have implications for the evolution of Hylaeochampsidae that currently is only known from the Cretaceous (Norell \& Clark 1990; Pol et al. 2009; Turner 2015). Should Pachycheilosuchus and Pietraroiasuchus be referred to Hylaeochampsidae, then NMS G.2016.21.1 would suggest this clade has a much longer evolutionary history than previously known. The type species Hylaeochampsa vectiana is known from the Early Cretaceous of the Isle of Wight (southern coast of the United Kingdom), whilst all other species consistently referred to Hylaeochampsidae are known from the Late Cretaceous of Europe (Clark \& Norell 1992; Martin 2007; Delfino et al. 2008a, b; PuértolasPascual et al. 2014). Therefore, NMS G.2016.21.1 potentially could extend the temporal range of Hylaeochampsidae, or a slightly more inclusive clade, into the Middle Jurassic, and geographically into the north of the United Kingdom.

However, it is possible that NMS G.2016.21.1, Pachycheilosuchus and Pietraroiasuchus form a clade of derived neosuchians that are basal to Eusuchia. The variable phylogenetic position of Pachycheilosuchus is one of the biggest issues in determining where NMS G.2016.21.1 belongs on the crocodyliform tree, second only to the specimen's general incompleteness. Pachycheilosuchus was originally described as a possible atoposaurid (Rogers 2003), but Turner (2015) recovered it at the base of Eusuchia. Other studies have recovered this species in radically different positions, such as: in a more basal position within Neosuchia, closer to the split with Tethysuchia 
(Adams 2014); as a derived neosuchian but basal to Eusuchia (Narváez et al. 2015); as a basal neosuchian, even more basal than the Tethysuchia-Eusuchia split (Tennant et al. 2016b); or in a clade with an assortment of hylaeochampsids and susisuchids (Schwarz et al. 2017). The phylogeny of Turner (2015) is consistent with Buscalioni et al. (2011) in the monophyly of Hylaeochampsidae, despite the fact that the latter study found Pietraroiasuchus as the sister group of Pachycheilosuchus (although they did not sample Acynodon). Young et al. (2016b) recovered Pachycheilosuchus and Pietraroiasuchus as sister taxa, and that clade was the sister taxon to Crocodylia. However, Young et al. (2016b) did not sample any other hylaeochampsids.

The incompleteness of NMS G.2016.21.1 hinders its inclusion into a rigorous phylogenetic analysis of Hylaeochampsidae, but new dentary characters are observed in multiple putative members of the clade and will be important in future systematic evaluations. The mandibular symphysis extends less than four alveoli in NMS G.2016.21.1, Pachycheilosuchus (Rogers 2003) and Pietraroiasuchus (Buscalioni et al. 2011), and it is shorter than five alveoli in Acynodon iberoccitanus (Martin 2007). In all these taxa, the dentary alveoli extend no deeper than the dorsal margin of the Meckelian canal. These characters could potentially be diagnostic of Hylaeochampsidae.

Several clades of small-to-medium-sized Mesozoic neosuchians have been suggested to be closely positioned to the origin of Eusuchia, including Hylaeochampsidae, Susisuchidae, Bernissartiidae and Paralligatoridae, although the taxonomic compositions of these clades vary among crocodyliform phylogenies (e.g., Turner \& Sertich 2010; Adams 2014; Turner 2015; Young et al. 2016b; Schwarz et al. 2017). However, the various phylogenetic analyses appear to converge on a divergence between the large-bodied and primarily aquatic neosuchian clades (Pholidosauridae + Dyrosauridae) and the relatively smaller-bodied, terrestrial or semi-aquatic clades (although the position of Goniopholididae is variable; Adams 2014; Turner 2015; Young et al. 2016b; Schwarz et al. 2017). Yet little is known about neosuchians before the Late Jurassic due to a patchy non-marine fossil record (Mannion et al. 2015; Tennant et al. 2016b). The earliest definitive record of pholidosaurid material comes from the Late Jurassic of Uruguay and France (Fortier et al. 2011). The Bathonian age for the putative pholidosaurid Anglosuchus was questioned by Watson (1911), and the specimens referred to this taxon cannot be located.

Discovery of a specimen morphologically similar to putative hylaeochampsids from the Middle Jurassic suggests that small body size, which is widespread among basal eusuchians, emerged early in Neosuchia. We remain cautious in this conclusion, however, because an accurate estimate of adult body size of NMS G.2016.21.1 cannot be determined due to its incomplete nature and likely juvenile status. Further investigation is required to elucidate the distribution, mode and magnitude of body size evolution among advanced neosuchians, and we suggest that the discovery of new Middle Jurassic fossils from places like the Isle of Skye may hold the key.

\section{Conclusion}

The new lower jaw from the Isle of Skye helps shed light on the evolution of crocodyliforms during the mysterious Middle Jurassic interval. Whilst it has several distinctive dentary characters, particularly in relation to the Meckelian canal and mandibular symphysis, we do not refer it to a new taxon due to its incompleteness. Based on similarities in the mandibular symphyseal suture and dentary alveoli, this specimen appears to have an affinity with the Early Cretaceous putative hylaeo- champsids Pachycheilosuchus trinquei and Pietraroiasuchus ormezzanoi. Furthermore, the anterior dentary and alveolar morphological variation described herein will hopefully contribute to future phylogenetic analyses, especially those including taxa referred to Hylaeochampsidae. Along with other discoveries from Skye, this new specimen shows that smallbodied neosuchians were diversifying in the Middle Jurassic, during a time when their fossil record is extremely poor.

\section{Acknowledgements}

Ian Butler (University of Edinburgh) performed the CT scanning in November 2015. For access to modern crocodilian specimens, we thank David Kizirian, David Dicky, Margret Arnold and Lauren Vonnahme at the American Museum of Natural History. We thank Alan Turner and another reviewer for insightful comments that improved the quality of the manuscript. HY was funded by the Royal Society Sino-British Incoming Postdoctoral Fellowship and the University of Edinburgh. JPT is funded by the National Environmental Research Council. Fieldwork by the University of Edinburgh and the PalAlba Group on the Isle of Skye was funded by Richard Deveira, the Edinburgh Zoo and Royal Zoological Society of Scotland, the Edinburgh Geological Society, the Systematics Research Fund (administered by the Linnean Society of London and the Systematics Association) and the University of Edinburgh. SLB's lab is funded by a Marie Curie Career Integration Grant (CIG 630652) and a Royal Society Research Grant (RG130018).

\section{References}

Adams, T. L. 2014. Small crocodyliform from the Lower Cretaceous (Late Aptian) of central Texas and its systematic relationship to the evolution of Eusuchia. Journal of Paleontology 88, 1031-49.

Anderson, F. W. 1948. Algal beds in the Great Estuarine Series of Skye. Proceedings of the Royal Physical Society of Edinburgh 23, 123-42.

Andrade, M. B., Edmonds, R., Benton, M. J. \& Schouten, R. 2011. A new Berriasian species of Goniopholis (Mesoeucrocodylia, Neosuchia) from England, and a review of the genus. Zoological Journal of the Linnean Society 163, S66-S108.

Andrews, C. W. 1913. A Descriptive Catalogue of the Marine Reptiles of the Oxford Clay, Part II. London: British Museum (Natural History). $285 \mathrm{pp}$.

Andrews, J. E. 1985. The sedimentary facies of a late Bathonian regressive episode: the Kilmaluag and Skudiburgh Formations of the Great Estuarine Group, Inner Hebrides, Scotland. Journal of the Geological Society 142, 1119-37.

Andrews, J. E. 1986. Microfacies and geochemistry of algal limestones from the Middle Jurassic of Scotland. Sedimentology 33, 499-520

Andrews, J. E. \& Walton, W. 1990. Depositional environments within Middle Jurassic oyster-dominated lagoons: an integrated litho-, bio- and palynofacies study of the Duntulm Formation (Great Estuarine Group, Inner Hebrides). Transactions of the Royal Society of Edinburgh: Earth Sciences 81, 1-22.

Averianov, A. O. 2000. Sunosuchus sp. (Crocodylomorpha, Goniopholididae) from the Middle Jurassic of Kirghisia. Journal of Vertebrate Paleontology 20, 776-79.

Benton, M. J. \& Clark, J. M. 1988. Archosaur phylogeny and the relationships of the Crocodylia. In Benton, M. J. (ed.) The Phy logeny and Classification of the Tetrapods Volume 1: Amphibians, Reptiles, Birds, 295-338. Oxford: Clarendon Press. 377 pp.

Bronzati, M., Montefeltro, F. C. \& Langer, M. C. 2015. Diversification events and the effects of mass extinctions on Crocodyliformes evolutionary history. Royal Society Open Science 2, 140385.

Brusatte, S. L., Young, M. T., Challands, T. J., Clark, N. D. L., Fischer, V., Fraser, N. C., Liston, J. J., Macfadyen, C. C. J., Ross, D. A., Walsh, S. \& Wilkinson, M. 2015. Ichthyosaurs from the Jurassic of Skye, Scotland. Scottish Journal of Geology 51(1), 43-55. 
Brusatte, S. L., Challands, T. J., Ross, D. A. \& Wilkinson, M. 2016. Sauropod dinosaur trackways in a Middle Jurassic lagoon on the Isle of Skye, Scotland. Scottish Journal of Geology 52(1), 1-9.

Brusatte, S. L. \& Clark. N. D. L. 2015. Theropod dinosaurs from the Middle Jurassic (Bajocian - Bathonian) of Skye, Scotland. Scottish Journal of Geology 51(2), 157-64.

Buscalioni, A. D., Piras, P., Vullo, R., Signore, M. \& Barbera, C. 2011. Early eusuchia crocodylomorpha from the vertebrate-rich Plattenkalk of Pietraroia (Lower Albian, southern Apennines, Italy). Zoological Journal of the Linnean Society 163, S199-S227.

Buscalioni, A. D. \& Sanz, J. L. 1990. Montsecosuchus depereti (Crocodylomorpha, Atoposauridae), new denomination for Alligatorium depereti Vidal, 1915 (Early Cretaceous, Spain): redescription and phylogenetic relationships. Journal of Vertebrate Paleontology 10, 244-54.

Clark, J. M., Xu, X., Forster, C. A. \& Wang Y. 2004. A Middle Jurassic "sphenosuchian" from China and the origin of the crocodylian skull. Nature 430, 1021-24.

Clark, J. M. \& Norell, M. A. 1992. The Early Cretaceous crocodylomorph Hylaeochampsa vectiana from the Wealden of the Isle of Wight. American Museum Novitates 3032, 1-19.

Clark, J. M. \& Sues, H. 2002. Two new basal crocodylomorph archosaurs from the Lower Jurassic and the monophyly of the Sphenosuchia. Zoological Journal of the Linnean Society 136, 77-95.

Clark, N. D. L., Boyd, J. D., Dixon, R. J. \& Ross, D. A. 1995. The first Middle Jurassic dinosaur from Scotland: a cetiosaurid? (Sauropoda) from the Bathonian of the Isle of Skye. Scottish Journal of Geology 31, 171-76.

Close, R. A., Davis, B. M., Walsh, S., Wolniewicz, A. S., Friedman, M. \& Benson, R. B. J. 2016. A lower jaw of Palaeoxonodon from the Middle Jurassic of the Isle of Skye, Scotland, sheds new light on the diversity of British stem therians. Palaeontology 59, 155-69.

Colbert, E. H. \& Mook, C. C. 1951. The Ancestral Crocodilian Protosuchus. Bulletin of the American Museum of Natural History $\mathbf{9}$, $143-82$.

Dal Sasso, C. \& Pasini, G. 2003. First record of pterosaurs (Diapsida, Archosauromorpha, Pterosauria) in the Middle Jurassic of Madagascar. Atti Della Societa Italiana Di Scienze Naturali E Del Museo Civico Di Storia Naturale in Milano 144, 281-296.

Daudin, F. M. 1802. Le crocodile du Mississipi. In Histoire Naturelle, Générale et Particulière des Reptiles; ouvrage faisant suit à l'Histoire Naturelle générale et particulière, composée par Leclerc de Buffon; et rédigée par C. S. Sonnini. Tome Second, 412-16. Paris: F. Dufart.

Delfino, M., Martin, J. E. \& Buffetaut, E. 2008a. A new species of Acynodon (Crocodylia) from the Upper Cretaceous (SantonianCampanian) of Villaggio del Pescatore, Italy. Palaeontology 51, 1091-106.

Delfino, M., Codrea, V., Folie, A., Dica, P., Godefroit, P. \& Smith, T. 2008b. A complete skull of Allodaposuchus precedens Nopcsa, 1928 (Eusuchia) and a reassessment of the morphology of the taon based on the Romanian remains. Journal of Vertebrate Paleontology 28, 111-22.

Evans, S. E., Barrett, P. M., Hilton, J., Butler, R. J., Jones, M. E. H., Liang, M.-M., Parish, J. C., Rayfield, E. J., Sigogneau-Russell, D. \& Underwood, C. J. 2006. The Middle Jurassic vertebrate assemblage of Skye, Scotland. In Barrett, P. M. \& Evans, S. E. (eds) Ninth International Symposium on Mesozoic Terrestrial Ecosystems and Biota, Abstracts and Proceedings, 36-39. London: The Nartural History Museum.

Evans, S. E. \& Milner, A. R. 1994. Middle Jurassic microvertebrate assemblages from the British Isles. In Fraser, N. C. \& Sues, H. (eds) In the Shadow of the Dinosaurs: Early Mesozoic Tetrapods, 303-21. Cambridge, UK: Cambridge University Press.

Evans, S. E. \& Waldman, M. 1996. Small reptiles and amphibians from the Middle Jurassic of Skye, Scotland. Museum of Northern Arizona Bulletin 60, 219-26.

Fiorelli, L. \& Calvo, J. O. 2008. New remains of Notosuchus terrestris Woodward, 1896 (Crocodyliformes: Mesoeucrocodylia) from Late Cretaceous of Neuquén, Patagonia, Argentina. Arquivos Do Museu Nacional, Rio de Janeiro 66, 83-124.

Flynn, J. J., Fox, S. R., Parrish, M., Ranivoharimanana, L. \& Wyss, A. R. 2006. Assessing diversity and palaeoecology of a Middle Jurassic microvertebrate assemblage from Madagascar. In Harris, J. D., Lucas, S. G., Spielmann, J. A., Lockley, M. G., Milner, A. R. C. \& Kirkland, J. I. (eds) The Triassic-Jurassic terrestrial transition. New Mexico Museum of Natural History and Science Bulletin 37, 476-89. Albuquerque: Authority of the State of New Mexico.
Fortier, D., Perea, D. \& Schultz, C. 2011. Redescription and phylogenetic relationships of Meridiosaurus vallisparadisi, a pholidosaurid from the Late Jurassic of Uruguay. Zoological Journal of the Linnean Society 163, S257-72.

Fortier, D. C. \& Schultz, C. L. 2009. A new neosuchian crocodylomorph (Crocodyliformes, Mesoeucrocodylia) from the Early Cretaceous of north-east Brazil. Palaeontology 52, 991-1007.

Fu, Q.-M., Ming, S.-Y. \& Peng, G.-Z. 2005. A new species of Sunosuchus from Zigong, Sichuan, China. Vertebrata PalAsiatica 43(1), 76-83.

Gao, K. \& Fox, R. C. 1998. New choristoderes (Reptilia: Diapsida) from the Upper Cretaceous and Palaeocene, Alberta and Saskatchewan, Canada, and phylogenetic relationships of Choristodera. Zoological Journal of the Linnean Society 124, 303-53.

Gao, Y. 2001. A new species of Hsisosuchus (Mesoeucrocodylia) from Dashanpu, Zigong Municipality, Sichuan Province. Vertebrata PalAsiatica 39, 177-84.

Gasparini, Z. B. \& Chong, G. 1977. Metriorhynchus casamiquelai n. sp. (Crocodilia, Thalattosuchia), a marine crocodile from the Jurassic (Callovian) of Chile, South America. Neues Jahrbuch für Geologie und Paläontologie, Abhandlungen 153, 341-60.

Göhlich, U. B., Chiappe, L. M., Clark, J. M. \& Sues, H.-D. 2005. The systematic position of the Late Jurassic alleged dinosaur Macelognathus (Crocodylomorpha: Sphenosuchia). Canadian Journal of Earth Sciences 42, 307-21.

Gomani, E. M. 1997. A crocodyliform from the Early Cretaceous Dinosaur Beds, northern Malawi. Journal of Vertebrate Paleontology 17, 280-94.

Harris, J. P. Hudson, \& J. D. 1980. Lithostratigraphy of the Great Estuarine Group (Middle Jurassic), Inner Hebrides. Scotish Journal of Geology 16, 231-50.

Holliday, C. M. \& Nesbitt, S. J. 2013. Morphology and diversity of the mandibular symphysis of archosauriforms. Geological Society, London, Special Publications 379, 555-71.

Holmden, C. \& Hudson, J. D. 2003. 87/86Sr and Sr/Ca investigation of Jurassic mollusks from Scotland: implications for paleosalinities and the $\mathrm{Sr} / \mathrm{Ca}$ ratio of seawater. Geological Society of America, Bulletin 115, 1249-64.

Hudson, J. D. \& Trewin, N. H. 2003. Chapter 11: Jurassic. In Trewin, N. H. (ed.) The Geology of Scotland (4th edition). London: The Geological Society. 576 pp.

Joffe, J. 1967. The "dwarf" crocodiles of the Purbeck Formation, Dorset: a reappraisal. Palaeontology 10, 629-639.

Knoll, F., Cuny, G., Mojon, P.-O., López-Antoñanzas, R. \& Huguet, D. 2013. A new vertebrate-, ostracod- and charophyte-bearing locality in the Middle Jurassic of the Grands Causses (southern France). Proceedings of the Geologists' Association 124, 525-29.

Knoll, F. \& López-Antoñanzas, R. 2014. The vertebrate fauna from the "stipite" layers of the Grands Causses (Middle Jurassic, France). Frontiers in Ecology and Evolution 2, 48. doi: 10.3389/ fevo.2014.0048.

Kriwet, J., Rauhut, O. W. M. \& Gloy, U. 1997. Microvertebrate remains (Pisces, Archosauria) from the Middle Jurassic (Bathonian) of southern France. Neues Jahrbuch für Geologie und Paläontologie Abhandlungen 206, 1-28.

Kuzmin, I. T., Skutschas, P. P., Grigorieva, O. I. \& Krasnolutskii, S. A. 2013. Goniopholid Crocodylomorph from the Middle Jurassic Berezovsk Quarry locality (Western Siberia, Russia). Proceedings of the Zoological Institute of the Russian Academy of Sciences 317, 452-58.

Maisch, M. W., Matzke, A. T., Pfretzschner, H. U., Sun, G., Stohr, H. \& Grossmann, F. 2003. Fossil vertebrates from the Middle and Upper Jurassic of the Southern Junggar Basin (NW China) results of the Sino-German Expeditions 1999-2000. Neues Jahrbuch für Geologie und Paläontologie Monatshefte 2003(5), 297-313.

Mannion, P. D., R. B. J. Benson, M. T. Carrano, J. P. Tennant, J. Judd, and R. J. Butler. 2015. Climate constrains the evolutionary history and biodiversity of crocodylians. Nat Commun 6, 8438 .

Martin, J. E. 2007. New material of the Late Cretaceous globidontan Acynodon iberoccitanus (Crocodylia) from southern France. Journal of Vertebrate Paleontology 27, 362-72.

Mook, C. C. 1921. Individual and age variations in the skulls of recent Crocodilia. Bulletin of the American Museum of Natural History 44, 51-66.

Morton, N. \& Hudson, J. D. 1995. Field guide to the Jurassic of the isles of Raasay and Skye, Inner Hebrides, NW Scotland. In Taylor, P. D. (ed.) Field Geology of the British Jurassic, 209-80. London \& Bath: The Geological Society. ii +286 pp.

Motani, R. 1997. Temporal and spatial distribution of tooth implantations in ichthyosaurs. In Callaway, J. M. \& Nicholls, E. L. (eds) 
Ancient Marine Reptiles, 81-103. San Diego, California: Academic Press. $501 \mathrm{pp}$.

Myrow, P. M. 1995. Thalassinoides and the enigma of Early Paleozoic open-framework burrow systems. Palaios 10, 58-74.

Narváez, I., Brochu, C. A., Escaso, F., Pérez-García, A. \& Ortega, F. 2015. New crocodyliforms from southwestern Europe and definition of a diverse clade of European Late Cretaceous basal eusuchians. PLOS ONE 10(11), e 0140679 .

Nesbitt, S. J. 2011. The Early evolution of Archosaurs: relationships and the origin of major clades. Bulletin of the American Museum of Natural History 352, 1-292.

Norell, M. A. \& Clark, J. M. 1990. A reanalysis of Bernissartia fagesii, with comments on its phylogenetic position and its bearing on the origin and diagnosis of the Eusuchia. Bulletin - Institut Royal des Sciences Naturelles de Belgique, Sciences de la Terre 60 $115-28$.

Ösi, A. 2008. Cranial osteology of Iharkutosuchus makadii, a Late Cretaceous basal eusuchian crocodyliform from Hungary. Neues Jahrbuch für Geologie und Paläontologie-Abhandlungen 248(3), 279-99.

Osmólska, H. 1972. Preliminary note on a crocodilian from the Upper Cretaceous of Mongolia. Acta Palaeontologia Polonica 27, 43-47.

Osmólska, H., Hua, S. \& Buffetaut, E. 1997. Gobiosuchus kielanae (Protosuchia) from the Late Cretaceous of Mongolia: anatomy and relationships. Acta Palaeontologica Polonica 42, 257-89.

Owen, R. 1874. Supplement to the fossil Reptilia of the Wealden (Hylaeochampsa), Number 6. Monograph of the Palaeontographical Society London 27(125), 1-7.

Pierce, S. E. \& Benton, M. J. 2006. Pelagosaurus typus Bronn, 1841 (Mesoeucrocodylia: Thalattosuchia) from the Upper Lias (Toarcian, Lower Jurassic) of Somerset, England. Journal of Vertebrate Paleontology 26, 621-35.

Pol, D., Ji, S., Clark, J. M., \& Chiappe, L. M. 2004. Basal crocodyliforms from the Lower Cretaceous Tugulu Group (Xinjiang, China), and the phylogenetic position of Edentosuchus. Cretaceous Research 25, 603-22.

Pol, D., Turner, A. H. \& Norell, M. A. 2009. Morphology of the Late Cretaceous Crocodylomorph Shamosuchus djadochtaensis and a discussion of neosuchian phylogeny as related to the origin of eusuchia. Bulletin of the American Museum of Natural History 324, 1-103.

Pol, D., Rauhut, O. W. M., Lecuona, A., Leardi, J. M., Xu, X. \& Clark, J. M. 2013. A new fossil from the Jurassic of Patagonia reveals the early basicranial evolution and the origins of Crocodyliformes. Biological Reviews 88, 862-72.

Pol, D. \& Apesteguía, S. 2005. New Araripesuchus remains from the early Late Cretaceous (Cenomanian - Turonian) of Patagonia. American Museum Novitates 3490, 1-38.

Pol, D. \& Norell, M. A. 2004a. A new Crocodyliform from Zos Canyon, Mongolia. American Museum Novitates 3445, 1-36.

Pol, D. \& Norell, M. A. 2004b. A New Gobiosuchid Crocodyliform Taxon from the Cretaceous of Mongolia. American Museum Novitates 3458, 1-31.

Puértolas-Pascual, E., Canudo, J. I. \& Moreno-Azanza, M. 2014. The eusuchian crocodylomorph Allodaposuchus subjuniperus sp. nov., a new species from the latest Cretaceous (Upper Maastrichtian) of Spain. Historical Biology 26, 91-109.

Rogers, J. V. 2003. Pachycheilosuchus trinquei, a new procoelous crocodyliform from the Lower Cretaceous (Albian) Glen Rose Formation of Texas. Journal of Vertebrate Paleontology 23, 12845.

Romer, A. S. 1956. Osteology of the reptiles. Chicago: University of Chicago Press. $\mathrm{xxi}+772 \mathrm{pp}$.

Salisbury, S. W. 2002. Crocodilians from the Lower Cretaceous (Berriasian) Purbeck Limestone Group of Dorset, Southern England. Special Papers in Palaeontology 68, 121-44.

Salisbury, S. W., Frey, E., Martill, D. M. \& Buchy, A.-C. 2003. A new crocodylian from the Lower Cretaceous Crato Formation of north-eastern Brazil. Paläeontographica Abteilung 270, 3-47.

Salisbury, S. W., Molnar, R. E., Frey, E. \& Willis, P. A. 2006. The origin of modern crocodyliforms: new evidence from the Cretaceous of Australia. Proceedings of the Royal Society of London B: Biological Sciences 273, 2439-48.

Salisbury, S. W. \& Naish, D. 2011. Crocodilians. In Batten, D. J. (ed.) English Wealden Fossils, 305-69. London: The Palaeontological Association. $769 \mathrm{pp}$.

Sassoon, J., Foffa, D. \& Marek, R. 2015. Dental ontogeny and replacement in Pliosauridae. Royal Society Open Science 2, 150384

Schwarz, D., Raddatz, M. \& Wings, O. 2017. Knoetschkesuchus langenbergensis gen. nov. sp. nov., a new atoposaurid crocodyliform from the Upper Jurassic Langenberg Quarry (Lower Saxony, northwestern Germany), and its relationships to Theriosuchus. PLOS ONE 12, e0160617.

Schwarz, D. \& Salisbury, S. W. 2005. A new species of Theriosuchus (Atoposauridae, Crocodylomorpha) from the Late Jurassic (Kimmeridgian) of Guimarota, Portugal. [Une nouvelle espèce de Theriosuchus (Atoposauridae, Crocodylomorpha) du Jurassique supérieur (Kimméridgien) de Guimarota]. Geobios 38, 779-802.

Soares, D. 2002. An ancient sensory organ in crocodilians. Nature $417,241-42$

Sweetman, S. C., Pedreira-segade, U. \& Vidovic, S. U. 2015. A new bernissartiid crocodyliform from the Lower Cretaceous Wessex Formation (Wealden Group, Barremian ) of the Isle of Wight, southern England. Acta Palaeontologica Polonica 60, 257-68.

Tennant, J. P. \& Mannion, P. D. 2014. Revision of the Late Jurassic crocodyliform Alligatorellus, and evidence for allopatric speciation driving high diversity in western European atoposaurids. PeerJ 2, e599, 1-37.

Tennant, J. P., Mannion, P. D. \& Upchurch, P. 2016a. Sea level regulated tetrapod diversity dynamics through the Jurassic/Cretaceous interval. Nature Communications 7, 12737.

Tennant, J. P., Mannion, P. D. \& Upchurch, P. 2016b. Environmental drivers of crocodyliform extinction across the Jurassic/Cretaceous transition. Proceedings of the Royal Society B: Biological Sciences 283, 20152840

Tennant, J. P., Mannion, P. D. \& Upchurch, P. 2016c. Evolutionary relationships and systematics of Atoposauridae (Crocodylomorpha: Neosuchia): implications for the rise of Eusuchia. Zoological Journal of the Linnean Society 177, 854-936.

Tong, H., Buffetaut, E. \& Suteethorn, V. 2002. Middle Jurassic turtles from southern Thailand. Geological Magazine 139, 687-97.

Turner, A. H. 2006. Osteology and phylogeny of a new species of Araripesuchus (Crocodyliformes?: Mesoeucrocodylia) from the Late Cretaceous of Madagascar. Historical Biology 18, 255-369.

Turner, A. H. 2015. A Review of Shamosuchus and Paralligator (Crocodyliformes, Neosuchia) from the Cretaceous of Asia. PlosOne 10, e 0118116.

Turner, A. H. \& Sertich, J. J. W. 2010. Phylogenetic history of Simosuchus clarki (Crocodyliformes?: Notosuchia) from the Late Cretaceous of Madagascar. Journal of Vertebrate Paleontology, Memoir 30(sp1), 177-236.

Waldman, M. \& Savage, R. J. G. 1972. The first Jurassic mammal from Scotland. Journal of the Geological Society, London 128, $119-25$.

Watson, D. 1911. Notes on some British Mesozoic crocodiles. Memoirs and Proceedings of the Manchester Literary and Philosophical Society 55, 1-13.

Whetstone, K. N. \& Whybrow, P. J. 1983. A "cursorial" crocodilian from the Triassic of Lesotho (Basutoland), southern Africa. Occasional Papers of the University of Kansas Museum of Natural History 106, 1-37.

Wilberg, E. E. W. 2015. A new metriorhynchoid (Crocodylomorpha, Thalattosuchia) from the Middle Jurassic of Oregon and the evolutionary timing of marine adaptations in thalattosuchian crocodylomorph. Journal of Vertebrate Paleontology 35, e902846.

Wills, S., Barrett, P. M. \& Walker, A. 2014. New dinosaur and crocodylomorph material from the Middle Jurassic (Bathonian) Kilmaluag Formation, Skye, Scotland. Scottish Journal of Geology 50, $183-90$.

Wu, X.-C., Sues, H.-D., \& Dong, Z.-M. 1997. Sichuanosuchus shuhanensis, a new ?Early Cretaceous protosuchian (Archosauria: Crocodyliformes) from Sichuan (China), and the monophyly of Protosuchia. Journal of Vertebrate Paleontology 17, 89-103.

Yang, C.-C. 1973. [A new fossil crocodile from Wuerho]. Memoirs of the Institute of Vertebrate Paleontology and Paleoanthropology Academia Sinica 11, 37-44. [In Chinese.]

Young, M. T., Brusatte, S. L., Ruta, M. \& Andrade, M. B. 2010. The evolution of Metriorhynchoidea (mesoeucrocodylia, thalattosuchia): An integrated approach using geometric morphometrics, analysis of disparity, and biomechanics. Zoological Journal of the Linnean Society 158, 801-59.

Young, M. T., Bell, M. A., Andrade, M. B. \& Brusatte, S. L. 2011 Body size estimation and evolution in metriorhynchid crocodylomorphs: implications for species diversification and niche partitioning. Zoological Journal of the Linnean Society 163, 1199-1216.

Young, M. T., Andrade, M. B., Etches, S. \& Beatty, B. L. 2013. A new metriorhynchid crocodylomorph from the Lower Kimmeridge Clay Formation (Late Jurassic) of England, with implications for the evolution of dermatocranium ornamentation in Geosaurini. Zoological Journal of the Linnean Society 169, 820-48. 
Young, M. T., Steel, L., Foffa, D., Price, T., Naish, D. \& Tennant, J. P. 2014. Marine tethysuchian crocodyliform from the AptianAlbian (Lower Cretaceous) of the Isle of Wight, UK. Biological Journal of the Linnean Society 113, 854-71.

Young, M. T., Tennant, J. P., Brusatte, S. L., Challands, T. J., Fraser, N. C. Clark, N. D. L. \& Ross, D. A. 2016a. The first definitive Middle Jurassic atoposaurid (Crocodylomorpha, Neosuchia), and a discussion on the genus Theriosuchus. Zoological Journal of the Linnean Society 176, 443-62.

Young, M. T., Hastings, A. K., Allain, R. \& Smith, T. J. 2016b. Revision of the enigmatic crocodyliform Elosuchus felixi de Lapparent de Broin, 2002 from the Lower-Upper Cretaceous boundary of Niger: potential evidence for an early origin of the clade Dyrosauridae. Zoological Journal of the Linnean Society. doi: 10.1111/ zoj.12452.

MS received 14 June 2016. Accepted for publication 10 March 2017. 